УДК 636.2.034.082.2(477)

\title{
ПАРАМЕТРИ ОСНОВНИХ ОЗНАК ПРОДУКТИВНОСТІ У ЗАВОДСЬКИХ ТИПАХ ВІТЧИЗНЯНИХ ПОРІД ХУДОБИ УКРАӤНИ
}

\author{
Почукалін Антон Євгенійович \\ кандидат сільськогосподарських наук, старший науковий співробітник \\ Інститут розведення і генетики тварин ім. М.В.Зубця НААН України \\ ORCID: 0000-0003-2280-5371 \\ E-mail: pochuk.a@ukr.net \\ Прийма Сергій Володимирович \\ науковий співробітник \\ Інститут розведення і генетики тварин ім. М.В.Зубця НААН України \\ ORCID: 0000-0001-9902-4325 \\ E-mail: priymas@i.ua \\ Різун Олег Володимирович \\ Інститут розведення і генетики тварин ім. М.В.Зубця НААН України \\ ORCID: 0000-0001-8205-3656 \\ E-mail: rizun.oleg@gmail.com
}

Порода, як динамічна структура, що об'єднує внутрішньопородні та заводські (зональні) типи, апробовані лінії та родини постійно перебуває у русі змін селекційних ознак. Заводські типи мають характерні риси за комплексом господарськи корисних ознак продуктивності, екстер'єру, відтворення. Для моніторингу молочної продуктивності корів у межах типів проведені дослідження на двох заводських типах української чорно-рябої (київський, харківський), чотирьох типах української червоної (східний, західний, центральний, таврійський) та шести типах української червоно-рябої (харківський, київський, вінницький, черкаський, буковинський, прилуцький) молочних порід. Для дослідження були включені показники: чисельність маточного поголів'я, структура типів за отеленнями, молочна продуктивність та жива маса корів у середньому та селекційного ядра первісток та повновікових корів. За чисельністю, слід відмітити заводські типи українських чорно-рябої та червоно-рябої молочних порід. Середня частка корів за типами складає 54 \%. Кількість племінних тварин у кращих племінних господарствах перевищує 3 тис. голів. Частка первісток у структурі типів висока і має діапазон від 19,5 \% у західному до 60,4 \% у таврійському типах. Надій корів у заводських типах має широку міжгрупову дифреренціацію. Так, у середньому за типами первісток $і$ повновікових корів надій має наступні коливання, які становлять відповідно 3782,6 ке ... 8784,3 ке; 2980,0 ке ... 8218,3 к2; 4737,2 к2 .. 9193,7 к2. Ліміти за надоєм корів селекційного ядра за відповідні періоди знаходяться в межах: 4562,5 ке ...9616,1 ке; 4835,0 ке .. 9109,8 к己 та 5600,0 к己 ...9981,5 к己. Найкращі показники за надоєм відмічено у корів київського та харківського заводських типів українських чорно-рябої та червоно-рябої молочних порід, у той час як за вмістом жиру і білка в молоці корови таврійського та центрального заводських типів української червоної молочної. Найвища жива маса корів спостерігається у повновікових корів, де кращі популяції типів мають показник понад 600 ке.

Ключові слова: українська чорно-ряба, українська червоно-ряба, українська червона, заводський тип, чисельність, молочна продуктивність, жива маса, отелення.

DOI: https://doi.org/10.32845/bsnau.Ivst.2021.2.19

Постановка проблеми. Моніторинг у селекції сільськогосподарських тварин і у молочному скотарстві зокрема - $€$ невід'ємною складовою тривалого процесу, оскільки дає можливість аналізувати рівень продуктивних ознак і популяційних процесів у породах. Крім того, важливими є дослідження з визначення стану та розвитку селекційних ознак у питаннях генеалогічної структури і заводських типах зокрема.

Аналіз досліджень. Як відомо, структура породи включає такі складові, як внутрішньопородні та зональні типи, заводські лінії та споріднені групи, родини. У процес селекції відбувається постійний рух між складовими породи, одні змінюють інших, деякі зникають, інші більш продуктивні створюються $[2,5,6]$. У сучасній селекції під впливом великомасштабної селекції значно посилилась оцінка та вплив окремих тварин на удосконалення порід. Роль бугаївплідників їх оцінка та їх тиск на удосконалення господарськи корисних ознак окремих племінних стад висвітлено і у вітчизняній науці [3, 4, 9-16].

Крім того, заслуговує на увагу питання моніторингу

за селекційними ознаками у вітчизняних породах великої рогатої худоби молочного напряму продуктивності. Українські чорно-ряба, червоно-ряба та червона молочні мають широку розгалуженість за внутрішньопородними і заводськими типами. Дослідженнями встановлений рівень ознак молочної продуктивності, екстер'єру та відтворення, який постійно змінюється під впливом економічних умов $[1,7,8]$.

Актуальність. Рівень селекційних ознак постійно перебуває під впливом генотипу і технологічних фракторів (температура, вологість, системи утримання та годівлі), тому постійно постає питання моніторингу цих процесів у структурі породи, а саме типах, лініях і родинах.

Мета. Дослідити стан популяцій заводських типів вітчизняних порід за наявністю маточного поголів'я, розподілом корів за отеленнями та рівнем молочної продуктивності корів.

Матеріали та методи дослідження. Матеріалом для досліджень були щорічні звіти про результати бонітування великої рогатої худоби 12-ти заводських типів трьох вітчизняних порід молочного напряму продуктивності. Для 
аналізу сформовані наступні заводські типи: таврійський (ТТ, 2 стад), центральний (ЦТ, 4), східний (СТ, 7), західний $(3 Т, 2)$ української червоної молочної; київський (КТЧР, 13 стад), харківський (ХТЧР, 5) української чорно-рябої молочної; черкаський (ЧТ, 20 стад), харківський (ХТЧЕ, 2), вінницький (ВТ, 11), буковинський (БТ, 1), прилуцький $(П Т, 5)$, київський (КТЧЕ, 3) української червоно-рябої молочної.

У дослідження були включені наступні показники: чисельність маточного поголів'я, структура типу за отеленнями, молочна продуктивність і жива маса корів у середньому та селекційного ядра. Біометрична обробка середньозваженої величини обраховувалась за загальновживаною методикою.

Результати досліджень та обговорення. За результатами досліджень встановлено, що маточне поголів'я черкаського типу української червоно-рябої та київського і харківського типів чорно-рябої молочних порід - $€$ найбільш чисельними. У той час коли заводські типи української червоної молочної, крім східного типу, мають найменше представництво (табл. 1). Частка корів у типах вітчизняних порід коливається від 29,7 \% у таврійському до 64,9\% у вінницького, за середнього значення у $54 \%$. Понад 1 тис. голів мають 3 господарства української червоної (СТ, 3Т) та по 5 господарств червоно-рябої (ЧТ, БТ, ПТ) і чорно-рябої (КТ, ХТ) молочних. Племінні заводи з розведення української чорнорябої молочної породи (харківський тип) - СК «Восток» та ТОВ АФ «Пісчанська» мають загальне поголів'я 3882 гол. та 2005 гол. відповідно. У господарствах ТОВ «Колос-2011» Кіровоградської (ЦТ) та ТОВ «Росія» Вінницької (ВТ) областей кількість племінних тварин не перевищує 20 голів, і становить відповідно 12 гол. та 19 гол.

Маточне поголів'я заводський типів вітчизняних порід

\begin{tabular}{|c|c|c|c|c|c|}
\hline \multirow{3}{*}{$\begin{array}{c}\text { Заводський } \\
\text { тип }\end{array}$} & \multirow{3}{*}{ Усboro } & \multicolumn{4}{|c|}{ У тому числі: } \\
\hline & & \multirow{2}{*}{ корів } & \multicolumn{3}{|c|}{ телиць віком, міс.: } \\
\hline & & & $6-12$ & $13-18$ & 18 \\
\hline TT & 532 & 158 & 151 & 65 & 158 \\
\hline ЦТ & 553 & 164 & 13271 & 135 & 964 \\
\hline CT & 5421 & 3001 & 798 & 795 & 827 \\
\hline 3T & 1647 & 802 & 256 & 281 & 308 \\
\hline КТЧР & 7315 & 4619 & 946 & 1049 & 701 \\
\hline XTYP & 7838 & 4502 & 1176 & 1040 & 1120 \\
\hline ЧТ & 10317 & 5969 & 1347 & 1322 & 1679 \\
\hline XTYE & 4072 & 2126 & 556 & 1034 & 356 \\
\hline BT & 4082 & 2650 & 603 & 549 & 280 \\
\hline БT & 1716 & 1085 & 172 & 178 & 281 \\
\hline חТ & 4864 & 2650 & 846 & 738 & 630 \\
\hline КТЧЕ & 1300 & 627 & 261 & 285 & 127 \\
\hline
\end{tabular}

Таблиця 2

Структура корів заводських типів за отеленнями

\begin{tabular}{|c|c|c|c|c|c|c|c|}
\hline \multirow{2}{*}{$\begin{array}{c}\text { Заводський } \\
\text { тип }\end{array}$} & \multirow{2}{*}{ Параметр } & \multicolumn{6}{|c|}{ Отелення: } \\
\hline & & $\mathrm{T}$ & $\|$ & IIII & IV-V & VIIIX & $X$ \\
\hline \multirow[t]{2}{*}{ TT } & гол. & 110 & 38 & 22 & 9 & 3 & - \\
\hline & $\%$ & 60,4 & 20,9 & 12,1 & 4,9 & 1,6 & - \\
\hline \multirow[t]{2}{*}{ ЦТ } & гол. & 273 & 129 & 77 & 60 & 15 & 4 \\
\hline & $\%$ & 48,9 & 23,1 & 13,8 & 10,8 & 2,7 & 0,4 \\
\hline \multirow[t]{2}{*}{ CT } & гол. & 1026 & 663 & 528 & 553 & 233 & - \\
\hline & $\%$ & 34,2 & 22,1 & 17,6 & 18,4 & 7,8 & - \\
\hline \multirow[t]{2}{*}{$3 T$} & гол. & 156 & 255 & 196 & 160 & 33 & 2 \\
\hline & $\%$ & 19,5 & 31,8 & 24,4 & 20,0 & 4,1 & 0,2 \\
\hline \multirow[t]{2}{*}{ KTЧP } & гол. & 1627 & 1262 & 867 & 626 & 226 & 14 \\
\hline & $\%$ & 35,2 & 27,3 & 18,8 & 13,5 & 4,9 & 0,3 \\
\hline \multirow[t]{2}{*}{ XTYP } & гол. & 1875 & 1386 & 644 & 495 & 85 & - \\
\hline & $\%$ & 41,8 & 30,9 & 14,4 & 11,0 & 1,9 & - \\
\hline \multirow[t]{2}{*}{ पТ } & гол. & 2614 & 1349 & 1006 & 903 & 254 & 5 \\
\hline & $\%$ & 42,6 & 22,0 & 16,4 & 14,7 & 4,1 & 0,1 \\
\hline \multirow[t]{2}{*}{ XTЧE } & гол. & 888 & 534 & 349 & 293 & 61 & 1 \\
\hline & $\%$ & 41,8 & 25,1 & 16,4 & 13,8 & 2,9 & 0 \\
\hline \multirow[t]{2}{*}{ BT } & гол. & 1096 & 686 & 493 & 304 & 70 & - \\
\hline & $\%$ & 41,4 & 26,9 & 18,6 & 11,5 & 2,6 & - \\
\hline \multirow[t]{2}{*}{ БT } & гол. & 469 & 313 & 149 & 126 & 26 & 2 \\
\hline & $\%$ & 43,2 & 28,8 & 13,7 & 11,6 & 2,4 & 0,2 \\
\hline \multirow[t]{2}{*}{ ПТ } & гол. & 877 & 869 & 539 & 567 & 175 & 7 \\
\hline & $\%$ & 28,9 & 28,6 & 17,8 & 18,7 & 5,8 & 0,2 \\
\hline \multirow[t]{2}{*}{ КTЧE } & гол. & 178 & 143 & 136 & 96 & 73 & 1 \\
\hline & $\%$ & 28,4 & 22,8 & 21,7 & 15,3 & 11,6 & 0,2 \\
\hline
\end{tabular}


Отримані дані розподілу корів за отеленнями засвідчили високу частку корів за першим отеленням, особливо у корів таврійського типу, у той час як найменша кількість первісток у структурі належить західному типу української червоної молочної. Корів з десятим отеленням у стадах нараховується 36 голів, що складає не більше 0,4 \% у типах.

У структурах корів за отеленнями селекційного ядра відбулись суттєві зміни, зменшилась частка первісток заводських типів (крім буковинського та прилуцького) порівняно 3 загальною структурою у середньому на 9,1 \% з амплітудою від 2,4 \% у корів вінницького до 18,4 \% таврійського типів. Крім того, збільшилась (крім КТЧЕ) частка корів за ІІ отеленням у середньому на 5,2 \%.

Структура корів за отеленнями селекційного ядра заводських типів

Таблиця 3

\begin{tabular}{|c|c|c|c|c|c|c|c|}
\hline \multirow{2}{*}{$\begin{array}{c}\text { Заводський } \\
\text { тип }\end{array}$} & \multirow{2}{*}{ Параметр } & \multicolumn{6}{|c|}{ Отелення: } \\
\hline & & I & II & III & IV-V & VIIIX & $X$ \\
\hline \multirow[t]{2}{*}{ TT } & гол. & 55 & 43 & 11 & 20 & 2 & - \\
\hline & $\%$ & 42,0 & 32,8 & 8,4 & 15,3 & 1,5 & - \\
\hline \multirow[t]{2}{*}{ ЦТ } & гол. & 89 & 61 & 48 & 41 & 9 & 2 \\
\hline & $\%$ & 35,6 & 24,4 & 19,2 & 16,4 & 3,6 & 0,8 \\
\hline \multirow[t]{2}{*}{ CT } & гол. & 290 & 388 & 294 & 246 & 88 & - \\
\hline & $\%$ & 22,2 & 29,7 & 22,5 & 18,8 & 6,7 & - \\
\hline \multirow[t]{2}{*}{$3 T$} & гол. & 41 & 131 & 124 & 96 & - & - \\
\hline & $\%$ & 10,5 & 33,4 & 31,6 & 24,5 & - & - \\
\hline \multirow[t]{2}{*}{ КТЧР } & гол. & 543 & 581 & 379 & 197 & 29 & - \\
\hline & $\%$ & 31,4 & 33,6 & 21,9 & 11,4 & 1,7 & - \\
\hline \multirow[t]{2}{*}{ XTYP } & гол. & 463 & 716 & 437 & 233 & 28 & - \\
\hline & $\%$ & 24,7 & 38,1 & 23,3 & 12,4 & 1,5 & - \\
\hline \multirow[t]{2}{*}{ पT } & гол. & 1077 & 767 & 607 & 469 & 87 & 2 \\
\hline & $\%$ & 35,8 & 25,4 & 20,2 & 15,6 & 2,9 & 0,1 \\
\hline \multirow[t]{2}{*}{ XTYE } & гол. & 216 & 189 & 118 & 63 & - & - \\
\hline & $\%$ & 36,9 & 32,3 & 20,1 & 10,8 & - & - \\
\hline \multirow[t]{2}{*}{ BT } & гол. & 598 & 483 & 295 & 146 & 10 & - \\
\hline & $\%$ & 39,0 & 31,5 & 19,3 & 9,5 & 0,7 & - \\
\hline \multirow[t]{2}{*}{ БT } & гол. & 318 & 196 & 99 & 52 & 2 & - \\
\hline & $\%$ & 47,7 & 29,4 & 14,8 & 7,8 & 0,3 & - \\
\hline \multirow[t]{2}{*}{ ПТ } & гол. & 643 & 673 & 320 & 260 & 46 & 2 \\
\hline & $\%$ & 33,1 & 34,6 & 16,5 & 13,4 & 2,4 & 0,1 \\
\hline \multirow[t]{2}{*}{ КТЧЕ } & гол. & 51 & 42 & 98 & 10 & 1 & - \\
\hline & $\%$ & 25,2 & 20,8 & 48,5 & 5 & 0,5 & - \\
\hline
\end{tabular}

Загалом відмічена диференціація за основними селекційними ознаками у заводських типів вітчизняних порід, особливо за надоями та живою масою (табл. 4). Більш високий надій (понад 8 т) мають корови харківського типу українських чорно-рябої та червоно-рябої молочних за усіма лактаціями. Низькими показниками надою та живої маси харак- теризуються корови таврійського та західного типів. Вміст жиру і білка в молоці у корів досліджуваних типів має сталий розвиток селекційних ознак продуктивності, за кращого їх прояву у таврійського, західного української червоної молочної та харківського української червоно-рябої молочних порід.

Таблиця 4

Молочна продуктивність і жива маса корів заводських типів, Mзв (lim)

\begin{tabular}{|c|c|c|c|c|}
\hline \multirow{2}{*}{$\begin{array}{c}\text { Заводський } \\
\text { тип (n) }\end{array}$} & \multirow{2}{*}{ Надій, кг } & \multicolumn{2}{|c|}{ Вміст (\%): } & \multirow{2}{*}{ Жива маса, кг } \\
\hline & & жиру & білка & \\
\hline \multicolumn{5}{|c|}{ У середньому } \\
\hline TT $(n=122)$ & $3782,6(3292-8252)$ & $3,88(3,73-3,90)$ & $3,30(3,30-3,33)$ & $526,9(520-590)$ \\
\hline ЦТ (n=445) & $6591,5(4259-8120)$ & $3,93(3,58-4,04)$ & $3,23(3,02-3,46)$ & $543,1(544-596)$ \\
\hline CT $(n=2236)$ & $6962,4(6388-7736)$ & $3,90(3,55-4,00)$ & $3,20(3,00-3,35)$ & $546,7(506-567)$ \\
\hline $3 T(n=620)$ & $5801,8(4785-6132)$ & $4,00(3,80-4,07)$ & 3,21 & $532,3(524-535)$ \\
\hline KTYP $(n=3585)$ & $7638,1(4860-11423)$ & $3,71(3,57-4,36)$ & $3,16(2,99-3,40)$ & $577,3(557-626)$ \\
\hline XTYP $(n=3421)$ & 8784,3 (6506-11031) & $3,97(3,51-4,15)$ & $3,03(3,00-3,24)$ & $586,9(557-626)$ \\
\hline ЧT $(n=4837)$ & $6716,3(3848-8483)$ & $3,76(3,59-4,05)$ & $3,19(3,01-3,36)$ & $561,6(433-675)$ \\
\hline XTYE (n=1311) & $8252,2(7445-9412)$ & $3,78(3,70-3,83)$ & $3,31(3,30-3,32)$ & $539,2(533-548)$ \\
\hline BT $(n=2066)$ & $7409,3(5200-9063)$ & $3,75(3,53-3,91)$ & $3,24(3,10-3,40)$ & $575,4(500-612)$ \\
\hline БТ $(n=973)$ & 5967,0 & 3,89 & 3,34 & 560,0 \\
\hline ПТ $(n=2287)$ & $7250,1(6351-9970)$ & $3,80(3,70-4,12)$ & $3,20(3,08-3,30)$ & $531,9(500-590)$ \\
\hline KTЧE $(n=490)$ & $6171,4(4895-7527)$ & $3,71(3,43-3,89)$ & $3,11(3,00-3,18)$ & $573,3(553-594)$ \\
\hline \multicolumn{5}{|c|}{ За I лактацію } \\
\hline $\mathrm{TT}(\mathrm{n}=50)$ & 2980,0 & 3,90 & 3,30 & 470,0 \\
\hline ЦТ $(n=211)$ & $6298,3(3760-7644)$ & $3,90(3,62-4,00)$ & $3,25(3,02-3,41)$ & $528,6(490-563)$ \\
\hline CT $(n=759)$ & $6619,9(5857-7583)$ & $3,85(3,69-4,00)$ & $3,18(3,30-3,35)$ & $512,2(494-555)$ \\
\hline $3 T(n=116)$ & $5333,1(4240-5825)$ & $3,87(3,80-3,90)$ & 3,19 & $492,4(480-498)$ \\
\hline
\end{tabular}




\begin{tabular}{|c|c|c|c|c|}
\hline \multirow{2}{*}{$\begin{array}{c}\text { Заводський } \\
\text { тип (n) }\end{array}$} & \multirow{2}{*}{ Надій, кг } & \multicolumn{2}{|c|}{ Вміст (\%): } & \multirow{2}{*}{ Жива маса, кг } \\
\hline & & жиру & білка & \\
\hline KTUP $(n=1283)$ & 7167,3 (4207-10819) & $3,67(3,55-4,34)$ & $3,15(2,99-3,41)$ & $537,8(478-583)$ \\
\hline XTYP (n=811) & 7948,0 (6472-10200) & $3,91(3,52-4,11)$ & $3,02(2,90-3,26)$ & $528,7(514-560)$ \\
\hline ЧТ $(n=1971)$ & $6386,6(3502-7743)$ & $3,72(3,50-4,01)$ & $3,16(3,01-3,37)$ & $519,5(390-621)$ \\
\hline XTЧE (n=242) & $8218,3(7116-8520)$ & $3,73(3,70-3,84)$ & $3,30(3,30-3,32)$ & $500,9(500-504)$ \\
\hline BT $(n=)$ & $7282,9(4500-8910)$ & $3,70(3,50-3,80)$ & $3,25(3,10-3,38)$ & $551,6(460-627)$ \\
\hline БT $(n=357)$ & 6232,0 & 3,89 & 3,34 & 505,0 \\
\hline$\Pi Т(n=829)$ & $6980,0(6343-9036)$ & $3,70(3,60-3,90)$ & $3,20(3,08-3,25)$ & $508,6(500-541)$ \\
\hline KTЧЕ $(n=129)$ & $6655,9(4483-7562)$ & $3,64(3,35-3,76)$ & $3,10(3,00-3,17)$ & $485,1(480-504)$ \\
\hline \multicolumn{5}{|c|}{ За III лактацію } \\
\hline TT $(n=34)$ & $4737,2(2820-8252)$ & $3,97(3,73-4,10)$ & $3,31(3,30-3,33)$ & $564,1(550-590)$ \\
\hline ЦТ (n=133) & $6781,1(4550-8518)$ & $3,97(3,58-4,04)$ & $3,17(3,01-3,51)$ & $614,4(592-640)$ \\
\hline CT $(n=915)$ & $7023,1(6435-7860)$ & $3,88(3,54-4,10)$ & $3,22(3,00-3,35)$ & $575,8(519-646)$ \\
\hline $3 T(n=289)$ & $6020,2(5140-6291)$ & $4,04(3,80-4,12)$ & 3,23 & $557,6(550-560)$ \\
\hline KTЧP $(n=1213)$ & 7887,6 (5320-11577) & $3,73(3,58-4,39)$ & $3,14(3,00-3,40)$ & $607,7(504-670)$ \\
\hline XTUP (n=1224) & $9193,1(6797-11520)$ & $3,99(3,52-4,14)$ & $3,07(3,00-3,20)$ & $620,4(534-680)$ \\
\hline ЧТ $(n=656)$ & $6876,3(4362-3945)$ & $3,78(3,59-4,12)$ & $3,21(3,02-3,36)$ & $603,7(478-714)$ \\
\hline XTЧE (n=566) & 8259,7 (7669-9840) & $3,79(3,70-3,82)$ & $3,31(3,30-3,31)$ & $568,3(562-585)$ \\
\hline BT $(n=691)$ & $7370,2(5500-8885)$ & $3,77(3,40-3,98)$ & $3,25(3,10-3,43)$ & $597,0(501-650)$ \\
\hline БТ $(n=303)$ & 5405,0 & 3,89 & 3,33 & 635,0 \\
\hline$\Pi \mathrm{CT}(\mathrm{n}=812)$ & 7104,8 (6108-10062) & $3,85(3,70-4,25)$ & $3,20(3,09-3,30)$ & $599,5(522-635)$ \\
\hline КТЧЕ (n=227) & $5891,2(4969-7507)$ & $3,77(3,50-3,88)$ & $3,13(3,00-3,20)$ & $605,8(600-609)$ \\
\hline
\end{tabular}

Виділення кращих корів для селекційного ядра має важливе значення для поліпшення господарськи корисних ознак та реалізації генетичного потенціалу молочної продуктивності. Перевага за надоєм корів селекційного ядра становить +771 кг порівняно зі загальною популяцією (табл. 5).
Найбільша перевага за надоєм спостерігається у корів київського (+2259,6 кг), харківського (+1363,9 кг) типів української червоно-рябої молочної, центрального (+870,3 кг) української червоної молочної та київського (+893,3 кг) української чорно-рябої молочної порід.

Таблиця 5

Молочна продуктивність і жива маса корів заводських типів селекційного ядра, Мзв (lim)

\begin{tabular}{|c|c|c|c|c|}
\hline \multirow{2}{*}{$\begin{array}{c}\text { Заводський } \\
\text { тип (n) }\end{array}$} & \multirow{2}{*}{ Надій, кг } & \multicolumn{2}{|c|}{ Вміст (\%): } & \multirow{2}{*}{ Жива маса, кг } \\
\hline & & жиру & білка & \\
\hline \multicolumn{5}{|c|}{ У середньому } \\
\hline TT $(n=99)$ & $4562,5(4105-8634)$ & $3,88(3,66-3,90)$ & $3,30(3,30-3,30)$ & $538,9(532-600)$ \\
\hline ЦТ (n=245) & $7461,8(4530-8710)$ & $3,91(3,57-4,09)$ & $3,19(3,02-3,43)$ & $544,2(488-605)$ \\
\hline CT $(n=1114)$ & $7306,0(6743-8060)$ & $3,87(3,55-4,00)$ & $3,20(3,30-3,35)$ & 547,7 (509-566) \\
\hline $3 T(n=271)$ & 6044,5 (5167-6243) & $4,04(3,80-4,10)$ & 3,19 & $536,4(531-560)$ \\
\hline KTЧP (n=941) & 8531,3 (5159-11612) & $3,73(3,58-4,35)$ & $3,18(3,01-3,41)$ & $544,1(504-633)$ \\
\hline XTЧP $(n=1772)$ & 9386,5 (7011-11606) & $3,93(3,51-4,23)$ & $3,12(3,01-3,35)$ & $594,8(563-629)$ \\
\hline ЧT $(n=2475)$ & $7071,1(4274-9413)$ & $3,80(3,59-3,99)$ & $3,19(3,08-3,38)$ & $569,1(491-675)$ \\
\hline XTЧE (n=444) & $9616,1(9116-9795)$ & $3,73(3,70-3,83)$ & $3,30(524-565)$ & $554,2(524-565)$ \\
\hline BT $(n=1241)$ & $7812,7(5500-9340)$ & $3,78(3,53-3,93)$ & $3,25(3,10-3,41)$ & $582,9(500-628)$ \\
\hline БТ $(n=421)$ & 6644,0 & 3,89 & 3,34 & 580,0 \\
\hline$\Pi \mathrm{C}(\mathrm{n}=1642)$ & $7711,5(6780-10762)$ & $3,70(3,10-4,02)$ & $3,20(3,08-3,30)$ & $538,8(510-611)$ \\
\hline КTЧE (n=162) & 8431,0 & 3,77 & 3,14 & - \\
\hline \multicolumn{5}{|c|}{ За I лактацію } \\
\hline $\mathrm{TT}(\mathrm{n}=20)$ & 4835,0 & 3,90 & 3,30 & 490,0 \\
\hline ЦТ $(n=97)$ & $7054,2(3870-8313)$ & $3,90(3,61-4,10)$ & $3,25(3,02-3,25)$ & $527,8(491-564)$ \\
\hline CT $(n=348)$ & 6591,5 (6047-7564) & $3,81(3,70-4,00)$ & $3,21(3,00-3,35)$ & $512,9(490-560)$ \\
\hline $3 T(n=25)$ & 6100,0 & 3,95 & 3,12 & 506,0 \\
\hline KTYP (n=375) & 8329 (4531-10903) & $3,66(3,57-4,34)$ & $3,15(3,00-3,41)$ & $516,6(481-583)$ \\
\hline XTYP $(n=358)$ & $9109,8(6329-10860)$ & $3,87(3,51-4,20)$ & $3,07(3,00-3,30)$ & $546,7(516-563)$ \\
\hline ЧT $(n=897)$ & $6538,3(4120-8602)$ & $3,73(3,59-4,01)$ & $3,19(3,08-3,36)$ & $517,5(460-623)$ \\
\hline XTYE (n=166) & $9097,3(8574-9304)$ & $3,74(3,70-3,83)$ & $3,30(3,30-3,30)$ & $504,1(502-505)$ \\
\hline BT $(n=504)$ & $7573,5(6192-9150)$ & $3,71(3,50-3,80)$ & $3,24(3,10-3,39)$ & $551,3(480-644)$ \\
\hline БТ $(n=48)$ & 6726,0 & 3,89 & 3,34 & 525,0 \\
\hline$\Pi Т(n=638)$ & $7272(6576-9365)$ & $3,70(3,60-3,90)$ & $3,20(3,08-3,31)$ & $518,3(516-541)$ \\
\hline KTYE $(n=50)$ & $7740,6(4513-8266)$ & $3,76(3,72-3,77)$ & $3,14(3,14-3,16)$ & 505,0 \\
\hline \multicolumn{5}{|c|}{ За III лактацію } \\
\hline TT $(n=29)$ & $5928,1(4504-8634)$ & $4,01(3,66-4,20)$ & $3,30(3,30-3,30)$ & $580,3(570-600)$ \\
\hline ЦТ $(n=90)$ & $7651,4(4620-8890)$ & $3,94(3,55-4,32)$ & $3,14(3,01-3,50)$ & $621,0(583-635)$ \\
\hline CT $(n=403)$ & $7724,2(6835-8524)$ & $3,86(3,55-4,08)$ & $3,21(3,00-3,35)$ & $555,2(524-580)$ \\
\hline
\end{tabular}




\begin{tabular}{|c|c|c|c|c|}
\hline \multirow{2}{*}{$\begin{array}{c}\text { Заводський } \\
\text { тип (n) }\end{array}$} & \multirow{2}{*}{ Надій, кг } & \multicolumn{2}{|c|}{ Вміст (\%): } & \multirow{2}{*}{ Жива маса, кг } \\
\hline & & жиру & білка & \\
\hline $3 T(n=140)$ & 5883,8 (5167-6282) & $4,01(3,80-4,13)$ & 3,24 & $557,4(555-560)$ \\
\hline KTЧP (n=299) & 8609,5 (5554-11880) & $3,84(3,58-4,38)$ & $3,20(3,01-3,41)$ & $560,9(510-625)$ \\
\hline XTЧP (n=598) & $9721,4(7401-12020)$ & $3,94(3,53-4,25)$ & $3,16(3,01-3,40)$ & $616,4(546-682)$ \\
\hline ЧТ $(n=901)$ & 7354,5 (4274-9685) & $3,78(3,59-4,12)$ & $3,19(3,08-3,35)$ & $612,5(512-714)$ \\
\hline XTЧE (n=108) & 9981,5 (9854-10259) & $3,73(3,70-3,80)$ & $3,31(3,30-3,32)$ & $589(565-600)$ \\
\hline BT $(n=330)$ & $7890,7(6000-9395)$ & $3,84(3,50-3,98)$ & $3,27(3,10-3,43)$ & $616,9(499-665)$ \\
\hline БT $(n=149)$ & 6277,0 & 3,89 & 3,33 & 650,0 \\
\hline ПТ $(n=592)$ & 7779,7 (6832-11269) & $3,70(3,50-4,08)$ & $3,20(3,09-3,33)$ & $617,4(533-685)$ \\
\hline КТЧЕ $(n=86)$ & $5600,2(4971-8836)$ & $3,86(3,78-3,88)$ & $3,20(3,15-3,21)$ & 611,0 \\
\hline
\end{tabular}

Також відмічено переваги за надоєм корів селекційного ядра за I та III лактації, які становлять 647,1 та 628,3 кг відповідно. Жива маса понад 600 кг спостерігається у повновікових корів центрального типу української червоної молочної, харківського типу української чорно-рябої та черкаського, вінницького, буковинського, прилуцького та київського типів української червоно-рябої порід.

Висновки. Заводські типи вітчизняних порід великої рогатої худоби мають широку диференціацію за господарськи корисними ознаками. За чисельністю і надоєм корів, слід відмітити київський та харківський типи української чорнорябої та харківський, черкаський типи української червонорябої молочних порід. Компоненти молока, а саме вміст жиру та білка у заводських типах за ряд лактацій мають сталий розвиток. Жива маса у повновікових корів шести типів перевищують 600 кг. Селекційне ядро у типах мають перевагу перед загальною популяцією за надоєм, особливо у корів київського та харківського української червоно-рябої молочної породи.

\section{Список використаної літератури.}

1. Бащенко М. І., Хмельничий Л. М. Особливості екстер'єру корів черкаського заводського типу української червонорябої молочної породи. Вісник Сумського державного аграрного університету. Серія «Тваринництво». Спец.вип. 2001. C. $26-28$

2. Гладій М. В., Полупан Ю. П., Базишина І. В., Почукалін А. Є., Коваль Т. П., Безрутченко І. М., Полупан Н. Л., Михайленко Н. Г. Генезис і перспективи червоної молочної худоби в Україні. Розведення і генетика тварин. 2016. Вип. 51. С. 41-59.

3. Ладика В. І., Хмельничий С. Л. Фенотипова консолідованість селекційних груп корів сумського внутрішньопородного типу української чорно-рябої молочної породи різного походження за лінійними ознаками екстер'єрного типу. Вісник Сумського національного аграрного університету. Серія «Тваринництво». 2019. - Вип. 3(38). C. 3-11. DOI: https://doi.org/10.32845/bsnau.Ivst.2019.3.1

4. Майборода М. М., Германчук С. Г. Розрахунок племінної цінності тварин. Науковий вісник НАУ. Київ. 2000. Вип. 21.

5. Почукалін А. Є., Прийма С. В., Різун О. В. Діахронічний розвиток заводських ліній та споріднених груп бурої карпатської худоби за поколіннями. Розведення i генетика тварин. 2020. Вип. 59. C. 141-158 DOI: https://doi.org/10.31073/abg.59.16

6. Почукалін А. Є., Прийма С. В., Різун О. В. Поліській м'ясній породі великої рогатої худоби - 20 років: минуле, сучасне і майбутнє розвитку селекційного досягнення. Таврійський науковий вісник. № 108. 2019. C. 172-176 DOI: https://doi.org/10.32851/2226-0099.2019.108.23

7. Почукалін А. Є., Прийма С. В., Різун О. В. Порівняльний аналіз основних господарськи корисних ознак корів заводських (зональних) типів української червоної молочної породи. Таврійський науковий вісник. 2018. № 100. Т. 2. С. $182-187$.

8. Почукалін А. Є., Прийма С. В., Різун О. В. Фенотипова характеристика генофонду центрального внутрішньопородного типу української червоно-рябої молочної породи. Розведення і генетика тварин. 2017. Вип. 54. С. 98-105.

9. Сакса Е. И. Оценка быков-производителей голштинской породы по качеству потомства. Молочное и мясное скотоводство. 2020. № 5. C. 23-28.DOI:10.33943/MMS.2020.20.46.004

10. Харитонов С. Н., Алтухова Н. С., Мельникова Е. Е., Осадчая О. Ю., Сермягин А. А. Селекционный индекс племенной ценности быков-производителей по молочной продуктивности потомства в симментальской породе крупного рогатого скота. Зоотехния. 2020. № 9. C. 2-5. DOI: 10.25708/ZT.2020.49.57.001

11. Bauer J., Pribyl L., Vostry L. Reliability of single-step genomic BLUP breeding values by multi-trait test-day model analysis. J. of Dairy Sci. 2015. V 98(7). P. 4999-5003.

12. Bonk S., Reichelt M., Teuscher F., Segelke D., Reinsch N. Mendelian sampling covariability of market effects and genetic values. Genetic Selection and Evolution. 2016. V. 18. P. 36. 6196.

13. Cunningham E. P., Tauebert H. Measuring the effect of change I selection indices. J. of Dairy Sci. 2009. V 92. P. 6192-

14. Guo G., Lund M. S., Zhang Y., Su G. Comparision between genomic predictions using daughter yield devation and conventional estimated breeding value as response variables. J. Anim Breed Genetics. 2010. V. 126(6). P. 423-432.

15. Leitch H. W. Comparison of international selection indexes fordairy cattle breeding. Interbull Bull. 1994. V 10. P. 1-7.

16. Polupan Yu. P., Melnik Yu. F., Biriukova O. D. Influence of genetic factors on the productivity of cows. Розведення і генетика тварин. 2019. Вип. 58. С. 41-51 DOI: https://doi.org/10.31073/abg.58.06 


\section{References:}

1. Bashchenko, M. I. and Khmel'nychyy, L. M., 2001. Osoblyvosti ekster"yeru koriv cherkas'koho zavods'koho typu ukrayins'koyi chervono-ryaboyi molochnoyi porody [Features of the exterior of Cherkasy local-type cows of the Ukrainian red-andwhite dairy breed]. Visnyk Sums'koho derzhavnoho ahrarnoho universytetu. Seriya «Tvarynnytstvo». Spets.vyp, pp. 26-28.

2. Hladiy, M. V., Polupan, Yu. P., Bazyshyna, I. V., Pochukalin, A. Ye., Koval', T. P., Bezrutchenko, I. M., Polupan, N. L. and Mykhaylenko, N. H., 2016. Henezys i perspektyvy chervonoyi molochnoyi khudoby v Ukrayini [Genesis and prospects of red dairy cattle in Ukraine]. Rozvedennya i henetyka tvaryn, no. 51, pp. 41-59.

3. Ladyka, V. I. and Khmel'nychyy, S. L., 2019. Fenotypova konsolidovanist' selektsiynykh hrup koriv sums'koho vnutrishn'oporodnoho typu ukrayins'koyi chorno-ryaboyi molochnoyi porody riznoho pokhodzhennya za liniynymy oznakamy ekster"yernoho typu [Phenotypic consolidation of selection groups of cows of Sumy intrabreed type of Ukrainian black-and-white dairy breed of different origin by linear features of exterior type]. Visnyk Sums'koho natsional'noho ahrarnoho universytetu. Seriya «Tvarynnytstvo», no. 3(38), pp. 3-11. DOI: https://doi.org/10.32845/bsnau.lvst.2019.3.1

4. Mayboroda, M. M. and Hermanchuk, S. H., 2000. Rozrakhunok pleminnoyi tsinnosti tvaryn [Calculation of breeding value of animals]. Naukovyy visnyk NAU, Kyyiv. no. 21, pp. 77-80.

5. Pochukalin, A. Ye., Pryyma, S. V. and Rizun, O. V., 2020. Diakhronichnyy rozvytok zavods'kykh liniy ta sporidnenykh hrup buroyi karpat-s'koyi khudoby za pokolinnyamy [Diachronic development of local lines and related groups of Brown Carpathian cattle by generations]. Rozvedennya i henetyka tvaryn, no. 59, pp. 141-158. DOI: https://doi.org/10.31073/abg.59.16

6. Pochukalin, A. Ye., Pryyma, S. V. and Rizun O. V., 2019. Polis'kiy m"yasniy porodi velykoyi rohatoyi khudoby - 20 rokiv: mynule, suchasne i maybutnye rozvytku selektsiynoho dosyahnennya [Polissya beef cattle breed is 20 years old: past, present and future development of selection achievement]. Tavriys'kyy naukovyy visnyk, no. 108, pp. 172-176. DOI: https://doi.org/10.32851/2226-0099.2019.108.23

7. Pochukalin, A. Ye., Pryyma, S. V. and Rizun, O. V., 2018. Porivnyal'nyy analiz osnovnykh hospodars'ky korysnykh oznak koriv zavods'kykh (zonal'nykh) typiv ukrayins'koyi chervonoyi molochnoyi porody [Comparative analysis of the main economically useful features of cows of local (zonal) types of Ukrainian red dairy breed]. Tavriys'kyy naukovyy visnyk, no. 100, vol. 2, pp. 182-187.

8. Pochukalin, A. Ye., Pryyma, S. V. and Rizun, O. V., 2017. Fenotypova kharakterystyka henofondu tsentral'noho vnutrishn'oporodnoho typu ukrayins'koyi chervono-ryaboyi molochnoyi porody [Phenotypic characteristics of the gene pool of the central intrabreed type of the Ukrainian red-and-white dairy breed]. Rozvedennya i henetyka tvaryn, no. 54, pp. 98-105.

9. Saksa, E. I., 2020. Otsenka byikov-proizvoditeley golshtinskoy porodyi po kachestvu potomstva [Evaluation of bullsproducers of the Holstein breed by the quality of the offspring]. Molochnoe i myasnoe skotovodstvo, no. 5, pp. 23-28. DOI:10.33943/MMS.2020.20.46.004

10. Haritonov, S. N., Altuhova, N. S., Melnikova E. E., Osadchaya, O. YU. and Sermyagin, A. A., 2020. Selektsionnyiy indeks plemennoy tsennosti byikov-proizvoditeley po molochnoy produktivnosti potomstva $v$ simmentalskoy porode krupnogo rogatogo skota [Selection index of breeding value of bulls-producers by milk productivity of offspring in Simmental cattle breed]. Zootehniya, no. 9. pp. 2-5. DOI: 10.25708/ZT.2020.49.57.001

11. Bauer, J., Pribyl, L. and Vostry, L., 2015. Reliability of single-step genomic BLUP breeding values by multi-trait test-day model analysis. J. of Dairy Sci, no. 98(7), pp. 4999-5003.

12. Bonk, S., Reichelt, M., Teuscher, F., Segelke, D. and Reinsch, N., 2016. Mendelian sampling covariability of market effects and genetic values. Genetic Selection and Evolution, no. 18, pp. 36.

13. Cunningham, E. P. and Tauebert, H., 2009. Measuring the effect of change I selection indices. J. of Dairy Sci, no. 92 , pp. 6192-6196.

14. Guo, G., Lund, M. S., Zhang, Y. and Su, G., 2010. Comparision between genomic predictions using daughter yield devation and conventional estimated breeding value as response variables. J. Anim Breed Genetics, no. 126(6), pp. 423-432.

15. Leitch, H. W., 1994. Comparison of international selection indexes fordairy cattle breeding. Interbull Bull. no. 10, pp. 1-7.

16. Polupan, Yu. P., Melnik, Yu. F. and Biriukova, O. D., 2019. Influence of genetic factors on the productivity of cows. Rozvedennya i henetyka tvaryn, no. 58, pp. 41-51. DOI: https://doi.org/10.31073/abg.58.06

\section{Pochukalin Anton Yevheniiovych, PhD of agricultural sciences, Senior Research Officer \\ Pryima Serhii Volodymyrovych, Research Officer \\ Rizun Oleh Volodymyrovych \\ Institute of Animal Breeding and Genetics nd. a. M.V.Zubets of NAAS (Chubynske, Ukraine)}

\section{Parameters of the main features of productivity in local types of domestic breeds of Ukraine}

The breed, as a dynamic structure that combines intra-breed and local (zonal) types, tested lines and families, is constantly on the move for changes in breeding traits. Local types have the characteristic features of a set of economically useful features of productivity, exterior, reproduction. A study was conducted to monitor the milk productivity of cows within the types, on two local types of Ukrainian black-and-white (Kyiv, Kharkiv), four types of Ukrainian red (Eastern, Western, Central, Taurian) and six types of Ukrainian red-and-white (Kharkiv, Kyiv, Vinnytsia, Cherkasy, Bukovyna, Pryluky) dairy breeds. The study included indicators: the number of females stock, the structure of types by calving, milk productivity and live weight of cows in the middle and the selection nucleus of firstborn and adult cows. According to the number, it should be noted the local types of Ukrainian black-and-white and Ukrainian red-and-white dairy breeds. The average share of cows by type is $54 \%$. The number of breeding animals in the best breeding farms exceeds 3 thousand heads. The share of firstborns in the structure of types is high and ranges from $19,5 \%$ in the Western to $60,4 \%$ in the Taurian types. Milk yield in local types has a wide intergroup differentiation. Thus, on average by type 
among firstborn and adult cows of milk yield has the following fluctuations, which are respectively $3782,6 \mathrm{~kg} \ldots 8784,3 \mathrm{~kg} ; 2980,0$ $\mathrm{kg} \ldots 8218,3 \mathrm{~kg} ; 4737,2 \mathrm{~kg} \ldots 9193,7 \mathrm{~kg}$. Limits on milk productivity of a selection nucleus for the corresponding periods are within: $4562,5 \mathrm{~kg} \ldots 9616,1 \mathrm{~kg} ; 4835,0 \mathrm{~kg} \ldots 9109,8 \mathrm{~kg}$ and 5600,0 kg...9981,5 kg. The best milk yield were observed in cows of Kyiv and Kharkiv local types of Ukrainian black-and-white and Ukrainian red-and-white dairy breeds, while in terms of fat and protein content in milk of cows of Taurian and Central local types of Ukrainian red dairy. The highest live weight of cows is observed in adult cows, where the best populations of types have an index of more than $600 \mathrm{~kg}$.

Key words: Ukrainian black-and-white, Ukrainian red-and-white, Ukrainian red, local type, number, milk productivity, live weight, calving.

Дата надходження до редакції: 15.04.2021 р. 